\title{
Microbial transformation of arsenic in Bengal floodplain
}

\author{
H. Afroz, A.A. Meharg \& C. Meharg \\ Institute for Global Food Security, Queens University Belfast, Belfast, UK
}

\begin{abstract}
Methylation is an important biotransformation process that limits the toxicity of arsenic (As) in soil. Here we investigated how geomorphology and paddy management influences As speciation, and the abundance and diversity of the arsM gene responsible for bacterial methylation of arsenic. Soil samples collected from paddy and non-paddy fields of Holocene and Pleistocene regions of Bangladesh were incubated under anaerobic conditions to identify how these treatments affected As speciation in soil solution as well as to investigate the changes in relative arsM copy no and diversity in soil. The Holocene soil had higher concentration of soil solution arsenic species (inorganic arsenic, dimethylarsinic acid (DMA), trimethylarsenic oxide (TMAO), with qPCR showing higher copy numbers of both $16 \mathrm{~S}$ and arsM in Holocene soil compared to Pleistocene soil. Lower soil Eh may explain the higher arsM copy number in Holocene soil, with arsenic methylation known to be increased under anaerobic conditions. The higher $\mathrm{pH}$ in Holocene soil may also explain the increase in 16S copy number, with bacteria known to be less abundant in acidic soils. Further to that amplicon sequencing showed an increased species richness (chao1) and diversity (Simpson) for both 16S and arsM in Holocene compare to Pleistocene soil. PiCrust analysis of the $16 \mathrm{~S}$ amplicon results showed the presence of arsenic metabolism related genes some of which were increased in Holocene compared to Pleistocene soil. The results showed that presence of As soil chemistry strongly correlates with arsenic transformation and copy number of arsenic metabolizing genes and bacterial as well as arsM gene diversity.
\end{abstract}

\section{INTRODUCTION}

Paddy soils in the Holocene regions of Bangladesh is elevated in inorganic arsenic (iAs), while Pleistocene soils are lower in iAS, most likely due to its and paddy management practices, such as flooding of irrigation of Holocene soils with As contaminated waters (Lu, et al., 2009). Several studies found that, Holocene floodplain contained higher total As compared to Pleistocene terrace soil (Chowdhury et al., 2017; Lu, et al., 2009; William et al., 2011). This is because, Holocene soils are less weathered and the parent material are still undergoing subsequent weathering process while the Pleistocene soils are highly weathered (William et al., 2011). As methylation is an important biotransformation process that catalyzes toxic iAs to less toxic methylated As species such as MMA (monomethylarsonic acid), DMA and TMAO. The rate of methylation depends on As species and the abundance and diversity of arsM gene in soil (Jia et al., 2014; Zhao et al., 2013). In this study, we investigated the effect of geomorphology and paddy management system on As speciation and diversity of arsM gene in Bangladeshi soil.

\section{MATERIAL AND METHODS}

\subsection{Soil sample collection incubation}

A total of 20 soil samples were collected from paddy and adjacent non-paddy fields across Holocene
(Araihazar Upazila) and Pleistocene regions (Madhupur Upazila) of Bangladesh. Field moist soils were incubated for 2 weeks under anaerobic condition to stimulate the activity of microbial population in soil. After two weeks, soil pore water and soils were collected and both soil and pore water immediately frozen and stored at $-20^{\circ}$ until subsequent analysis. $\mathrm{pH}$ and Eh was recorded in replicated microcosms by inserting an $\mathrm{Eh} / \mathrm{pH}$ meter inti the soil at harvest. Arsenic species in 0.4-micron Millipore membrane filtered soil pore waters (iAs, DMA and TMAO) were determined using a Dionex IC chromatographic system interfaced with ICP-MS (ICS-5000 DC, Thermo Scientific).

\subsection{DNA extraction, $q P C R$ and Amplicon sequencing}

Soil DNA was extracted using the Powerlyzer $^{\circledR}$ PowersSoil ${ }^{\circledR}$ DNA isolation kit (MOBIO Laboratories, Inc.) following the manufacturer's instructions. Soil DNA was amplified for bacterial 16S and arsM gene using specific primer pairs 16S_1369F/16S_1492R (Jia et al., 2014) and arsMF1/arsMR2 (Jia et al., 2013), respectively and relative copy no was measured by qPCR on the Eppendorf mastercycler (Realplex ${ }^{4}$, Hamburg, Germany) using SYBR green (PrimerDesign, USA). Following purification and quantification soil DNA samples were sent to Centre for Genomic Research institute, University of Liverpool for amplicon sequencing of the 16S rDNA and arsM gene on the Illumina Miseq using 250 paired end sequencing. 
a)
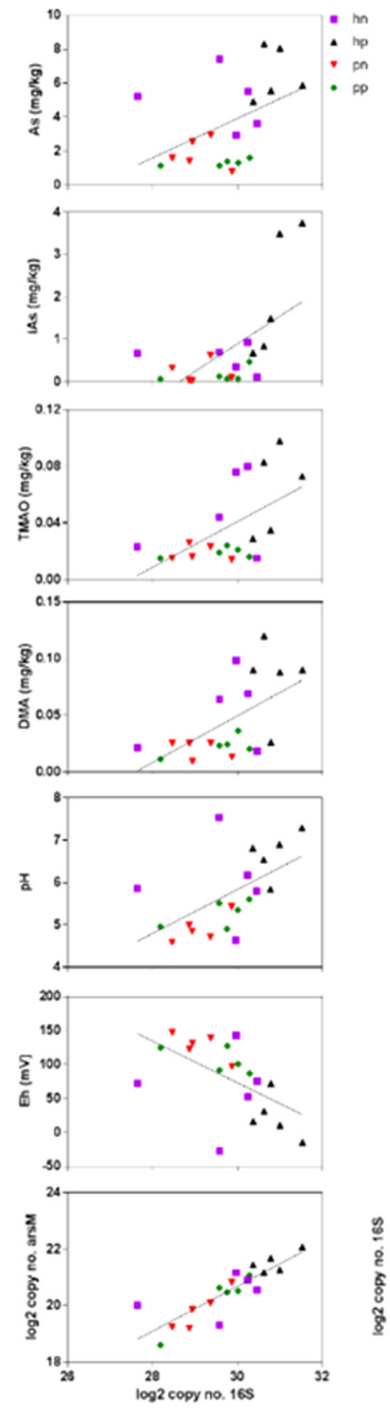

b)
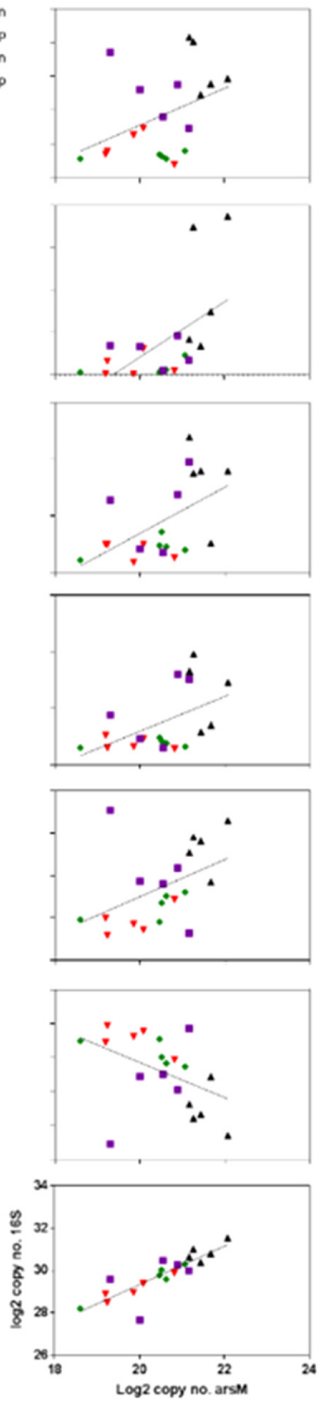

Figure 1. Linear Relationships for bacterial 16S (a) and arsM (b) gene copy no. versus soil As, soil solution As species, $\mathrm{pH}$ and $\mathrm{Eh}$. The line on each graph is the regression line for this parameter. "hn" represents Holocene non-paddy "hp" represents Holocene paddy, "pn" Pleistocene non-paddy, "pp" Pleistocene paddy.

Sequences were analyzed using QIIME version 1.8 (Caporaso et al., 2010) followed by statistical analysis in R.

\subsection{Characterization of soils}

The soil samples were oven dried $\left(70^{\circ} \mathrm{C}\right.$ for $\left.48 \mathrm{~h}\right)$ to constant weight and analyzed for t-As using ICP-MS.

\subsection{Statistical analysis}

Statistical analysis was performed in Minitab version 16 (Minitab, PA, USA) and Graphpad prism7.

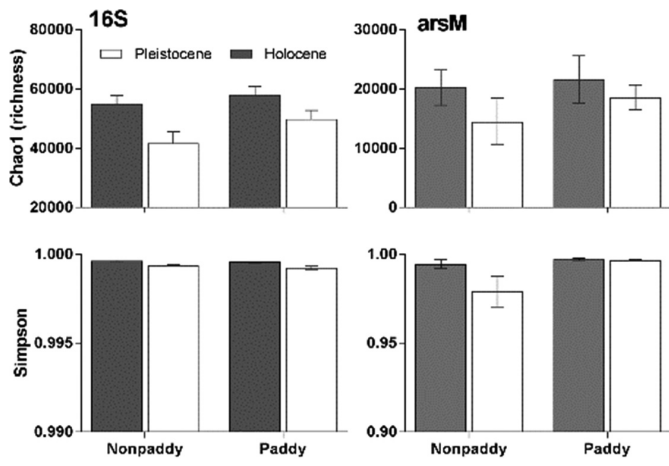

Figure 2. Alpha diversity (Richness and Simpson evenness) in bacterial $16 \mathrm{~S}$ and arsM gene. Significant differences $(p<0.05)$ was observed for geomorphology (Holocene/Pleistocene).

\section{RESULTS AND DISCUSSION}

\subsection{Soil solution As species, $p H$, Eh and $q P C R$}

The concentration of soil As, soil solution As species and relative copy no of bacterial $16 \mathrm{~S}$ and arsM gene were higher in Holocene soils compared to Pleistocene soils. The linear relationship between bacterial 16S and arsM gene copy no with chemical parameters (soil As, soil solution As species, $\mathrm{pH}$ and $\mathrm{Eh}$ ) is shown in Figure 1.

The strong linear relationships of $16 \mathrm{~S}$ and arsM gene copy with soil $\mathrm{pH}$ and Eh suggests that, these are the key factors that regulating the DNA copy no and As speciation in soil. High redox potential and acidic $\mathrm{pH}$ in Pleistocene soils leads to lower arsM gene copy no in that soils. Because arsM gene is redox sensitive and more active under anaerobic condition (Jia et al., 2013, 2014). In contrast, no significant Paddy management effect was observed in this study. The Pleistocene soils either from paddy and non-paddy soils were less variable in different fields while the Holocene non-paddy soils were more variable.

\subsection{Diversity of Bacterial 165 and arsM gene}

Alpha diversity measures showed higher species richness (chao1) and overall diversity (Simpson) for both $16 \mathrm{~S}$ and arsM gene in Holocene compared to Pleistocene soil. While this effect was significant for both $16 \mathrm{~S}$ and arsM, it was more pronounced in arsM gene (Fig. 2).

\section{CONCLUSION}

Overall, the concentration of soil As, pore water As species and the abundance of arsM and other As metabolism related genes was shown to vary in two different geomorphic units of Bangladesh, with chemical 
and biological parameters correlating. Future investigations will focus on metagenomics analysis to further explore these results.

\section{ACKNOWLEDGEMENTS}

The research work was funded by Commonwealth Scholarship Commission, UK.

\section{REFERENCES}

Caporaso, J.G., Kuczynski, J., Stombaugh, J., Bittinger, K., Bushman, F.D., Costello, E.K., Fierer, N., Peña, A.G., Goodrich, J.K., Gordon, J.I., Huttley, Kelley, S.T., Knights, D., Koenig, J.E., Ley, R.E., Lozupone, C.A., McDonald, D., Muegge, B.D., Pirrung, M., Reeder, J., Sevinsky, J.R., Turnbaugh, P.J., Walters, W.A., Widmann, J., Yatsunenko, T., Zaneveld, J. \& Knight, R. 2010. QIIME allows analysis of high-throughput community sequencing data. Nat. Methods 7(5): 335-336.

Chowdhury, M.T.A., Deacon, C.M., Jones, G.D., Huq, S.M.I., Williams, P.N., Hoque, A.F.M.M., Winkel, L.H.E., Price, A.H., Norton, G.J. \& Meharg, A.A. 2017. Arsenic in Bangladeshi soils related to physiographic region, paddy management, and mirco- and macro-elemental status. Sci. Total Environ. 590: 406-415.
Jia, Y., Huang, H., Zhong, M., Wang, F., Zhang, L. \& Zhu, Y. 2013. Microbial arsenic methylation in soil and rice rhizosphere. Environ. Sci. Technol. 47(7): 3141-3148.

Jia, Y., Huang, H., Chen, Z. \& Zhu, Y. 2014. Arsenic uptake by rice is influenced by microbe-mediated arsenic redox changes in the rhizosphere. Environ. Sci. Technol. 48(2): 1001-1007.

Lu, Y., Adomako, E.E., Solaiman, A.R.M., Islam, M.R., Deacon, C., Williams, P.N., Rahman, G.K.M.M. \& Meharg, A.A. 2009. Baseline soil variation is a major factor in arsenic accumulation in Bengal delta paddy rice. Environ. Sci. Technol. 43(6): 1724-1729.

Williams, P. N., Zhang, H., Davison, W., Meharg, A. A., Hossain, M., Norton, G. J., Brammer, H. \& Islam, R.M. 2011. Organic matter-solid phase interactions are critical for predicting arsenic release and plant uptake in Bangladesh paddy soils. Environ. Sci. Technol. 45(14): 6080-6087.

Zhao, F., Harris, E., Yan, J., Ma, J., Wu, L., Liu, W., McGrath, S.P., Zhou, J.Z. \& Zhu, Y.G. 2013. Arsenic methylation in soils and its relationship with microbial arsM abundance and diversity, and as speciation in rice. Environ. Sci. Technol. 47(13): 7147-7154. 